Modern American Literature 
Edinburgh Critical Guides to Literature

Series Editors: Martin Halliwell, University of Leicester and

Andy Mousley, De Montfort University

Published Titles:

Gothic Literature, Andrew Smith

Canadian Literature, Faye Hammill

Women's Poetry, Jo Gill

Contemporary American Drama, Annette J. Saddik

Shakespeare, Gabriel Egan

Asian American Literature, Bella Adams

Children's Literature, M. O. Grenby

Contemporary British Fiction, Nick Bentley

Renaissance Literature, Siobhan Keenan

Scottish Literature, Gerard Carruthers

Contemporary American Fiction, David Brauner

Contemporary British Drama, David Lane

Medieval Literature I300-I500, Pamela King

Contemporary Poetry, Nerys Williams

Victorian Literature, David Amigoni

Modern American Literature, Catherine Morley

Modernist Literature, Rachel Potter

Forthcoming Titles in the Series:

Restoration and Eighteenth-Century Literature, Hamish Mathison

Romantic Literature, Serena Baiesi

African American Literature, Jennifer Terry

Postcolonial Literature, Dave Gunning 


\section{Modern American Literature}

Catherine Morley 
For my sisters, Deirdre, Elaine and Rachel, whose support during the writing of this book has been immeasurable.

\section{And for Hilary}

(C) Catherine Morley, 2012

Edinburgh University Press Ltd

22 George Square, Edinburgh EH8 9 LF

www.euppublishing.com

Typeset in I I. 5/I3 Ehrhardt

by Servis Filmsetting Ltd, Stockport, Cheshire, and

printed and bound in Great Britain by

CPI Group (UK) Ltd, Croydon, CRo 4 YY

A CIP record for this book is available from the British Library

ISBN 978 o 748625062 (hardback)

ISBN 978 o 748625079 (paperback)

ISBN 978 o 74863072 I (webready PDF)

ISBN 978 o 748668298 (epub)

ISBN 978 o 748668304 (Amazon ebook)

The right of Catherine Morley

to be identified as author of this work

has been asserted in accordance with

the Copyright, Designs and Patents Act 1988. 